\title{
REFINEMENT OF THE X-RAY DATA FOR HYDROTUNGSTITE FROM CALACALANI, BOLIVIA
}

\author{
Th. G. Sahama and MartTi Lehtinen
}

\begin{abstract}
Sahama, Th. G. and Lehtinen, Martiti 1971: Refinement of the X-ray data for hydrotungstite from Calacalani, Bolivia. Bull. Geol. Soc. Finland 43, 89-91.

Single crystal X-ray precession photographs verify the hydrotungstite (U. S. National Museum No. 104901) from Calacalani, Bolivia, to be monoclinic (pseudo-orthorhombic) with the space group $P 2, P m$ or $P 2 / m$. Unit cell parameters are: $a_{0}=7.379 A, b_{0}=6.901 A, c_{0}=3.748 A, \beta=90^{\circ} 22^{\prime}$. Non-space group extinctions were found for $b k 0$ and $b 00$ with $b \neq 2 \mathrm{n}$. The powder pattern was indexed. The crystal structure evidently resembles that of molybdic acid. On the basis of the X-ray data, the setting by Kerr and Young is modified by interchanging the $b$ - and $c$-axes. In the new notation the optic axial plane is parallel to 001 .
\end{abstract}

Th. G. Sabama and Martti Lebtinen, Department of Geology, University of Helsinki, Finland.

Kerr and Young (1944) gave detailed chemical, optical and physical data for the tungstite $\left(\mathrm{H}_{2} \mathrm{WO}_{4}\right)$ and hydrotungstite $\left(\mathrm{H}_{2} \mathrm{WO}_{4} \cdot \mathrm{H}_{2} \mathrm{O}\right)$ which occur in the tungstic ocher of the Calacalani tungsten deposit in the Oruro district, Bolivia. Hydrotungstite was presented as a new species. On the basis of its optical properties this mineral was considered probably monoclinic. The X-ray powder pattern, photographed with the Phragmén-Bohlin camera, could not be indexed and, accordingly, no unit cell data were reported.

Later, the X-ray powder pattern of hydrotungstite was photographically recorded by Mitchell (1963) using a $11.46 \mathrm{~cm}$ diameter camera. He noticed a marked similarity between the pattern of hydrotungstite and that of synthetic molybdic acid $\left(\mathrm{H}_{2} \mathrm{MoO}_{4} \cdot \mathrm{H}_{2} \mathrm{O}\right)$ as given by Lindqvist (1950). Assuming for hydrotungstite a monoclinic (pseudo-orthorhombic) structure similar to that for molybdic acid, the powder pattern of hydrotungstite could be indexed using the Hesse-Lipson procedure. The parameters of the supposed monoclinic cell were given. No doubling of any $b 0 l$ and $h k l$ reflections could be detected, thus indicating that the departure of the $\beta$-angle from $90^{\circ}$ must be but slight. The lattice was considered definitely primitive with a possible space group $P 2 / \mathrm{m}$. The absence of the $b k 0$ reflections when $b$ is odd, characteristic of molybdic acid, could not be demonstrated on the basis of the powder pattern alone.

Through the courtesy of Dr. George Switzer, 
of the U. S. National Museum, Washington D. C., a chip of the original hydrotungstite specimen No. 104901, used by Mitchell, was obtained. The powder pattern of this specimen (Phillips Norelco, filtered copper radiation, internal silicon standard) was recorded. In addition, single crystal precession photographs were taken about $b$ - and $c$-axes of both twinned

TABLE 1

Powder pattern of hydrotungstite (U. S. National Museum No. 104901) from Calacalani, Bolivia.

\begin{tabular}{|c|c|c|c|c|}
\hline \multicolumn{2}{|l|}{ I } & $\mathrm{d}_{\text {meas }}$. & $\mathrm{d}_{\text {calc. }}$ & hkl \\
\hline 100 & $\ldots \ldots \ldots$ & 6.91 & 6.90 & 010 \\
\hline 12 & $\ldots \ldots \ldots$ & 3.75 & 3.75 & 001 \\
\hline 12 & $\ldots \ldots \ldots$ & 3.69 & 3.69 & 200 \\
\hline 67 & $\ldots \ldots \ldots$ & 3.453 & 3.450 & 020 \\
\hline 16 & $\ldots \ldots \ldots$ & 3.295 & 3.294 & 011 \\
\hline 19 & $\ldots \ldots \ldots$ & 3.253 & 3.254 & 210 \\
\hline 6 & $\ldots \ldots \ldots$ & 2.639 & 2.637 & $20 \overline{1}$ \\
\hline 6 & $\ldots \ldots \ldots$ & 2.620 & 2.621 & 201 \\
\hline 7 & $\ldots \ldots \ldots$ & 2.534 & $\left\{\begin{array}{l}2.538 \\
2.520\end{array}\right.$ & $\left\{\begin{array}{l}021 \\
220\end{array}\right.$ \\
\hline & & & $\int 2.464$ & $\int 21 \overline{1}$ \\
\hline 4 & $\cdots \cdots \cdots$ & 2.459 & $\{2.450$ & $\{211$ \\
\hline 27 & $\ldots \ldots \ldots$ & 2.301 & 2.300 & 030 \\
\hline 5 & $\ldots \ldots \ldots$ & 2.094 & 2.095 & $22 \overline{1}$ \\
\hline 4 & $\ldots \ldots \ldots$ & 2.083 & 2.087 & 221 \\
\hline 12 & $\ldots \ldots \ldots$ & 1.958 & $\{1.961$ & 031 \\
\hline 2 & & 1877 & 11.952 & $\begin{array}{l}230 \\
00 ?\end{array}$ \\
\hline 3 & $\ldots \ldots \ldots$ & 1.845 & $\begin{array}{l}1.8 / 4 \\
1.845\end{array}$ & 400 \\
\hline 2 & $\ldots \ldots \ldots$ & 1.812 & 1.813 & 102 \\
\hline 15 & $\ldots \ldots \ldots$ & 1.725 & 1.725 & 040 \\
\hline 2 & $\ldots \ldots \ldots$ & 1.665 & 1.666 & 202 \\
\hline 2 & $\ldots \ldots \ldots$ & 1.627 & 1.627 & 420 \\
\hline 2 & $\ldots \ldots$ & 1.607 & 1.605 & $\left\{\begin{array}{l}411 \\
12 ?\end{array}\right.$ \\
\hline 5 & $\ldots \ldots \ldots$ & 1.564 & 1.563 & 240 \\
\hline 4 & $\ldots \ldots \ldots$ & 1.444 & 1.444 & $24 \overline{1}$ \\
\hline 3 & $\ldots \ldots \ldots$ & 1.380 & 1.380 & 050 \\
\hline
\end{tabular}

TABLE 2

Unit cell parameters of hydrotungstite and of molybdic acid.

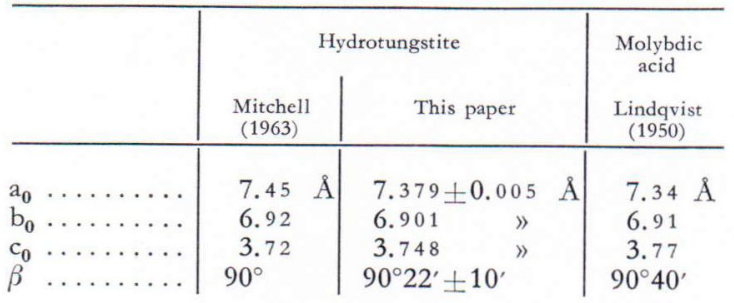

and untwinned crystals. The untwinned crystals were obtained by cutting out homogeneous fragments from twinned crystals. The cutting was made with a razor blade under the binocular microscope.

Because the data obtained will slightly modify those previously adopted for hydrotungstite, the results of this study will be briefly summarized in the following.

The precession photographs of hydrotungstite reveal a primitive monoclinic cell. The only systematic absences are the non-space group extinctions for $b k 0$ and $b 00$ with $b \neq 2 \mathrm{n}$. The space group is thus $P 2, P m$ or $P 2 / m$. The unit cell dimensions measured from the precession photographs and refined on the basis of the indexed powder pattern (Table 1) are compiled in Table 2. For comparison, this table also reproduces the data for hydrotungstite reported by Mitchell (op. cit.) and those for molybdic acid by Lindqvist (op. cit.) Precession photographs about the $b$-axis of twinned crystals show 201 as the twin plane.

The powder pattern of Table 1 agrees essentially with that previously given by Mitchell. The differences between the two powder patterns are probably caused by the differing recording techniques. The doubling of the $b 0 \mathrm{l}$ and $h \mathrm{kl}$ lines is well demonstrated in Table 1.

It is evident that the crystal structure of hydrotungstite resembles closely that of molybdic acid.

The setting used in Table 2 differs from that indicated by Kerr and Young (op. cit., Fig. 2 on p. 196) in that $b$ and $c$ are interchanged. The optical orientation was tested under the polarizing microscope on crystal flakes which had been photographed with the precession camera. The optic axial plane is parallel to 001 , in other words, subperpendicular to the $3.748 A$ axis. The optical orientation may be summarized as follows: $\alpha \| b, \beta$ subparallel to $c, \gamma$ subparallel to $a$. The extinction angle $\alpha \wedge c(\alpha \wedge b$ in the notation of this paper $)=3^{\circ}$ reported by Kerr and Young remains unexplained. 
The chemical composition found for hydrotungstite by Kerr and Young (op. cit., Table 3 on p. 200)., viz., $\mathrm{H}_{2} \mathrm{WO}_{4} \cdot \mathrm{H}_{2} \mathrm{O}$ with $Z=2$, and the unit cell dimensions given in this paper
(Table 2) yield a density of 4.66. This figure is close to the pycnometric density value 4.60 given by Kerr and Young.

\section{REFERENCES}

Kerr, Paul F. and Young, Ford (1944) Hydrotungstite, a new mineral from Oruro, Bolivia. Amer. Miner., vol. 29 , p. 192.

LINDQVist, IngVar (1950) The crystal structure of the yellow molybdic acid, $\mathrm{MoO}_{3} \cdot 2 \mathrm{H}_{2} \mathrm{O}$. Acta Chem. Scand., vol. 4, p. 650.
Mitchell, Richard S. (1963) X-ray data for hydrotungstite. Amer. Miner., vol. 48, p. 935.

Manuscript received, May 20, 1970. 